Article

\title{
Symbiotic Co-Culture of Scenedesmus sp. and Azospirillum brasilense on N-Deficient Media with Biomass Production for Biofuels
}

\author{
Jose R. Contreras-Angulo ${ }^{1}$, Teresa M. Mata ${ }^{2, * \mathbb{D}}$, Sara P. Cuellar-Bermudez ${ }^{3}$, \\ Nidia S. Caetano ${ }^{2,4} \oplus$, Rashmi Chandra ${ }^{1}$, J. Saul Garcia-Perez ${ }^{1}$, Koenraad Muylaert ${ }^{3}$ and \\ Roberto Parra-Saldivar ${ }^{1}$ (D) \\ 1 Tecnologico de Monterrey, Campus Monterrey, Ave. Eugenio Garza Sada 2501, \\ Monterrey 64849, NL, Mexico; joser_ca@hotmail.com (J.R.C.-A.); rashmichandra@tec.mx (R.C.); \\ garcia.saul87@gmail.com (J.S.G.-P.); r.parra@tec.mx (R.P.-S.) \\ 2 LEPABE-Laboratory for Process Engineering, Environment, Biotechnology and Energy, Faculty of \\ Engineering, University of Porto (FEUP), R. Dr. Roberto Frias S/N, 4200-465 Porto, Portugal; nsc@isep.ipp.pt \\ 3 Laboratory of Aquatic Biology, KU Leuven Kulak, E. Sabbelaan 53, 8500 Kortrijk, Belgium; \\ sapaulina@hotmail.com (S.P.C.-B.); koenraad.muylaert@kuleuven.be (K.M.) \\ 4 CIETI, Department of Chemical Engineering, School of Engineering (ISEP), Polytechnic of Porto (P.Porto), \\ R. Dr. Antonio Bernardino de Almeida 431, 4249-015 Porto, Portugal \\ * Correspondence: tmata@fe.up.pt
}

Received: 20 December 2018; Accepted: 23 January 2019; Published: 29 January 2019

check for updates

\begin{abstract}
The treatment of nitrogen-deficient agriculture wastewater, arising from the vegetable and fruit processing, is a significant problem that limits the efficiency of its biological treatment. This study evaluates the effectiveness of the symbiotic co-culture of Azospirillum brasilense and Scenedesmus sp., under two nitrogen levels $\left(8.23 \mathrm{mg} \mathrm{L}^{-1}\right.$ and $\left.41.17 \mathrm{mg} \mathrm{L}^{-1}\right)$ and mixing systems (aeration and magnetic stirring), aiming to simultaneously use the $\mathrm{N}$-deficient media for their growth while producing biomass for biofuels. Microalgae growth and biomass composition, in terms of protein, carbohydrate and fatty acid contents, were evaluated at the end of the exponential growth phase (15 days after inoculation). Results show that the symbiotic co-culture of microalgae-bacteria can be effectively performed on nitrogen-deficient media and has the potential to enhance microalgae colony size and the fatty acid content of biomass for biofuels. The highest biomass concentration $\left(103 \pm 2 \mathrm{mg} \cdot \mathrm{L}^{-1}\right)$ was obtained under aeration, with low nitrogen concentration, in the presence of A. brasilense. In particular, aeration contributed to, on average, a higher fatty acid content ( $48 \pm 7 \%$ dry weight (DW)) and higher colony size $\left(164 \pm 21 \mu \mathrm{m}^{2}\right.$ ) than mechanical stirring (with $39 \pm 2 \%$ DW and $134 \pm 21 \mu^{2}$, respectively) because aeration contribute to better mass transfer of gases in the culture. Also, co-culturing contributed in average, to higher colony size $\left(155 \pm 21 \mu \mathrm{m}^{2}\right)$ than without A. brasilense $\left(143 \pm 21 \mu^{2}\right)$. Moreover, using nitrogen deficient wastewater as the culture media can contribute to decrease nitrogen and energy inputs. Additionally, A. brasilense is approved and already extensively used in agriculture and wastewater treatment, without known environmental or health issues, simplifying the biomass processing for the desired application.
\end{abstract}

Keywords: Azospirillum brasilense; microalgae-bacteria co-culturing; mixing system; nitrogen concentration; Scenedesmus sp.

\section{Introduction}

Microalgae are photosynthetic microorganisms that can grow relatively fast, even under harsh environmental conditions [1], and have the capability to produce biomass rich in lipids, 
proteins and other compounds [2], which can be used for biofuels and a range of other products following a biorefinery framework [3]. The current interest on microalgae cultivation for energy production, coupled with the need for more sustainable wastewater treatment processes, has made microalgae-based wastewater treatment an economical and environmentally promising alternative compared to conventional treatment processes [4].

The treatment of nitrogen-deficient wastewater, particularly from vegetable and fruit processing, represents a significant problem [5], requiring the addition of nitrogen compounds in order to successful achieve aeration treatment [6], or for better chemical oxygen demand (COD) removal efficiencies by biological treatment [7]. However, this procedure has the disadvantage of increasing operating costs and may result in final effluent with residual nitrogen [5]. Alternatively, a new approach is presented in this study, based on the utilization of nitrogen fixing microalgae-bacteria consortiums [8], which can result in high biomass productivity [9] and lower operating costs [10]. Additionally, the resulting biomass can be used for biofuels production with lower operating costs, based on the more efficient microalgae/bacteria cultivation system [11], low energy consumption harvesting technologies [12], and eco-efficient extraction/purification techniques [13,14].

Bacteria can provide additional carbon dioxide $\left(\mathrm{CO}_{2}\right)$ for the microalgae culture [15], reducing aeration and $\mathrm{CO}_{2}$ pumping costs. Additionally, the bacteria metabolism is able to enhance the uptake of nutrients by microalgae because of the mineralization of organic matter present in the medium [16]. Some bacteria species are capable of establishing mutualistic interactions with microalgae [17]. An important group of these bacteria species are the plant growth-promoting bacteria (PGPB), which are commonly used in agriculture to enhance plant development and to increase production yields [18]. Some of these PGPB are also known to have beneficial effects in co-culturing with microalgae, and thus are also named microalgae growth promoting bacteria (MGPB).

Among the MGPB, Azospirillum, a genus of free living nitrogen-fixing bacteria, is capable of establishing synergistic and mutualistic relations with microalgae [17]. Nitrogen fixation by Azospirillum consists of converting the atmospheric nitrogen $\left(\mathrm{N}_{2}\right)$ into ammonium $\left(\mathrm{NH}_{4}\right)$, being the oxygen and ammonium concentrations in the culture media the main factors limiting the nitrogen fixation. The mixing system and the initial nitrogen concentration also directly affects both the oxygen and nitrogen concentration in the culture media, thus is also necessary to evaluate their effect in the co-culturing process. In addition to nitrogen fixation, Azospirillum releases compounds such as Indole-3-acetic acid (IAA), an auxin related to growth and stress tolerance enhancement in microalgae [19]. Being an aerobic bacteria, Azospirillum can also provide $\mathrm{CO}_{2}$ for microalgae and consume $\mathrm{O}_{2}$ produced by photosynthesis [20], a factor that may enhance microalgae growth. In particular, Azospirillum brasilense (A. brasilense) is one of the most well-studied nitrogen-fixing bacteria, widely distributed in soils and plant's roots. It is extensively used in agriculture to enhance plant growth and to promote bio-fertilization. It is approved for use in large scale applications for food, cosmetics and wastewater treatment, without known environmental or health issues [21].

Several studies demonstrated the efficiency of Azospirillum sp. as a MGPB in enhancing growth, biomass production and nutrient removal in immobilized co-culturing with Chlorella sp. for simultaneous wastewater treatment and biomass production [22-26]. Synechococcus elongatus is one of the cyanobacteria species co-cultured with Azospirillum using immobilized cultures, which enhanced growth of the microalgae due the present of the bacteria [27]. Most of the experiments regarding to A. brasilense co-culturing use immobilized systems. Thus, there is a knowledge gap in its application in suspended cultures, widely used in microalgae cultivation, both in closed (photobioreactors) and open (ponds) systems. Hence, in this work the microalgae Scenedesmus sp. was co-cultured with A. brasilense in suspended culture in order to evaluate its potential application and adaptation as an MGPB in bulk production systems.

Scenedesmus sp. is a widely used species for biomass production due to its relatively fast growth compared with other microalgae species, suitable for both outdoor culture and large scale cultivation [28]. Scenedesmus sp. growth has been studied for wastewater treatment [29,30], biofuels 
production [31,32] and food applications [33]. There are some previous publications about the co-culturing of Scenedesmus with different bacteria in wastewater, showing that it increases biomass production due to a higher $\mathrm{CO}_{2}$ concentration in the media [34], or its suitability to degrade complex pollutants such as crude oil [35]. However, to the best of the authors' knowledge, there is no previous work about the effect of $A$. brasilense co-cultured with Scenedesmus sp. in suspended cultures, even though Scenedesmus sp. is one of the most promising alternatives for large-scale cultivation for biomass production, wastewater treatment and other applications. As this could be the first experimental study involving the co-culture of $A$. brasilense and Scenedesmus sp., in this work an exploratory experimental design was performed, in which two mixing systems (aeration and magnetic stirring), two nitrogen levels $\left(8.23 \mathrm{mg} \mathrm{L}^{-1}\right.$ and $\left.41.17 \mathrm{mg} \mathrm{L}^{-1}\right)$ and the presence or absence of bacteria were evaluated in order to analyze their effects on the co-culture. The purpose of selecting two different mixing systems for the experiment, aerated versus stirred systems, was to provide two different oxygen levels to be tested in this study: a higher oxygen level provided by the aerated system and a lower oxygen level provided by the magnetic stirring. This is because it is known that the A. brasilense nitrogenase activity can be inhibited by oxygen, affecting its performance as MGPB [36]. Also, two different nitrogen concentrations were tested in the experiment, as it is known that nitrogen concentration has a key role in the establishment of a symbiosis between bacteria and microalgae, and strongly influences and nitrogen fixation of $A$. brasilense [37]. Biomass composition in terms of proteins, carbohydrates and fatty acids was also evaluated to identify a possible metabolic response of Scenedesmus sp.

\section{Materials and Methods}

\subsection{Culture Conditions and Inoculum Preparation}

Scenedesmus sp. (UTEX 1589, University of Texas, Austin, TX, USA) and A. brasilense (ATCC 29145, Manassas, VA, USA) were used in all the experiments. A modified BBM was used for microalgae cultures, i.e. to the original UTEX BBM it was added vitamin B12 solution, biotin, and thiamine [38]. The $\mathrm{pH}$ was initially adjusted to 6.5-6.6. $\mathrm{BBM}$ macronutrients are (in $\mathrm{g} \cdot \mathrm{L}^{-1}$ ): $\mathrm{NaNO}_{3}, 0.25 ; \mathrm{CaCl}_{2} \cdot 2 \mathrm{H}_{2} \mathrm{O}$, $0.025 ; \mathrm{MgSO}_{4} \cdot 7 \mathrm{H}_{2} \mathrm{O}, 0,075 ; \mathrm{K}_{2} \mathrm{HPO}_{4} \cdot 3 \mathrm{H}_{2} \mathrm{O}, 0.075 ; \mathrm{KH}_{2} \mathrm{PO}_{4}, 0.175 ; \mathrm{NaCl}, 0,025$ and micro-nutrients (in mg. $\mathrm{L}^{-1}$ ): $\mathrm{Na}_{2}$ EDTA, 4.5; $\mathrm{FeCl}_{3} \cdot 6 \mathrm{H}_{2} \mathrm{O}, 0.582 ; \mathrm{MnCl}_{2} \cdot 4 \mathrm{H}_{2} \mathrm{O}, 0.246 ; \mathrm{ZnCl}_{2}, 0.03 ; \mathrm{CoCl}_{2} \cdot 6 \mathrm{H}_{2} \mathrm{O}, 0.012$ : $\mathrm{NaMoO}_{4} \cdot 2 \mathrm{H}_{2} \mathrm{O}, 0.024$. A. brasilense was maintained in an Azospirillum (AZ) medium, initially adjusted to $\mathrm{pH} 7$ using potassium hydroxide. The $\mathrm{AZ}$ medium was composed by the following nutrients (in g. $\mathrm{L}^{-1}$ ): $\mathrm{C}_{4} \mathrm{H}_{6} \mathrm{O}_{5}, 5 ; \mathrm{K}_{2} \mathrm{HPO}_{4} \cdot 3 \mathrm{H}_{2} \mathrm{O}, 0.5 ; \mathrm{FeSO}_{4}, 0.500 ; \mathrm{MnCl}_{2} \cdot 4 \mathrm{H}_{2} \mathrm{O}, 0.010 ; \mathrm{MgSO}_{4} \cdot 7 \mathrm{H}_{2} \mathrm{O}, 0.200$; $\mathrm{NaCl}, 0.100 ; \mathrm{NaMoO}_{4} \cdot 2 \mathrm{H}_{2} \mathrm{O}, 0.002 ;$ and $\mathrm{CaCl}_{2} \cdot 2 \mathrm{H}_{2} \mathrm{O}, 0.020$.

A. brasilense cells were grown in $500 \mathrm{~mL}$ Erlenmeyer flasks containing $450 \mathrm{~mL}$ of $\mathrm{AZ}$ medium. Each flask was kept in thermostatic water bath at $36 \pm 1{ }^{\circ} \mathrm{C}$ under continuous agitation by magnetic stirring (around $150 \mathrm{rpm}$ ) at room conditions. Scenedesmus sp. cells were grown in $1 \mathrm{~L}$ Erlenmeyer flasks containing $800 \mathrm{~mL}$ of BBM at room temperature, light/dark cycles of $12 / 12 \mathrm{~h}$ and light intensity of $15 \mu \mathrm{mol}$ photons $\cdot \mathrm{m}^{-2} \cdot \mathrm{s}^{-1}$. Each flask was mixed using an $8 \mathrm{~cm}$ magnetic stirrer at about $60 \mathrm{rpm}$, and continuously aerated using a $5 \mathrm{~mm}$ glass tube diffuser placed at the bottom of the flask at a flow rate of about $500 \mathrm{~mL} \cdot \mathrm{min}^{-1}$.

For the inoculum preparation, Scenedesmus sp. was harvested by centrifugation (Centurion 4000r, Chichester, West Sussex, UK) at $2500 \mathrm{rpm}$ for $10 \mathrm{~min}$, and washed three times with saline solution $(0.8 \%$ $\mathrm{NaCl}$ ). Microalgae inoculum was adjusted to an optical density at $750 \mathrm{~nm}\left(\mathrm{OD}_{750}\right)$ of 0.8 (approximately $8 \times 10^{6}$ cells) with saline solution. A. brasilense was harvested by centrifugation at $5000 \mathrm{rpm}$ for $15 \mathrm{~min}$, and washed three times with a saline solution. A. brasilense inoculum was adjusted to an optical density at $540 \mathrm{~nm}\left(\mathrm{OD}_{540}\right)$ of 1.0 (approximately $1 \times 10^{9}$ cells) with a saline solution.

For the microalgae/bacteria co-culture, $500 \mathrm{~mL}$ Erlenmeyer flasks were used as bioreactors. Flasks were maintained under room temperature, light/dark cycles of $12 / 12 \mathrm{~h}$, at light intensity of $100 \mu \mathrm{mol}$ photons $\cdot \mathrm{m}^{-2} \mathrm{~s}^{-1}$. BBM with $20 \%\left(8.23 \mathrm{mg} \cdot \mathrm{L}^{-1}\right)$ and $100 \%\left(41.17 \mathrm{mg} \cdot \mathrm{L}^{-1}\right)$ of nitrogen content was tested with two different mixing conditions: air injection $\left(250 \mathrm{~mL} \cdot \mathrm{min}^{-1}\right)$ or magnetic stirring $(60 \mathrm{rpm})$. 
A volume of $8 \mathrm{~mL}$ of Scenedesmus inoculum along with $2 \mathrm{~mL}$ of $A$. brasilense inoculum were added to 450 $\mathrm{mL}$ of sterile medium in each flask. Final bacteria/microalgae ratio was maintained as 30 cells/cells.

\subsection{Experimental Design and Statistical Analysis}

In this study, three factors were evaluated: A. brasilense presence, mixing system, and initial nitrogen concentration in the culture media, with two levels each, corresponding to a $2^{3}$ factorial experimental design.

A total of 8 experimental treatments were performed to assess all the possible combinations of factors levels as shown in Table 1. Four replicates per treatment $(n=4)$ were performed.

Table 1. Experimental design conditions.

\begin{tabular}{cccc}
\hline Treatments & A. brasilense & Mixing System & Nitrogen \\
\hline 1 & Yes (+) & Aeration $(+)$ & $41.17 \mathrm{mg} \cdot \mathrm{L}^{-1}(+)$ \\
2 & Yes (+) & Aeration (+) & $8.23 \mathrm{mg} \cdot \mathrm{L}^{-1}(-)$ \\
3 & Yes (+) & Magnetic stirred (-) & $41.17 \mathrm{mg} \cdot \mathrm{L}^{1}(+)$ \\
4 & Yes (+) & Magnetic stirred (-) & $8.23 \mathrm{mg} \cdot \mathrm{L}^{-1}(-)$ \\
5 & No (-) & Aeration (+) & $41.17 \mathrm{mg} \cdot \mathrm{L}^{-1}(+)$ \\
6 & No (-) & Aeration (+) & $8.23 \mathrm{mg} \cdot \mathrm{L}^{-1}(-)$ \\
7 & No (-) & Magnetic stirred (-) & $41.17 \mathrm{mg} \cdot \mathrm{L}^{-1}(+)$ \\
8 & No (-) & Magnetic stirred (-) & $8.23 \mathrm{mg} \cdot \mathrm{L}^{-1}(-)$ \\
\hline
\end{tabular}

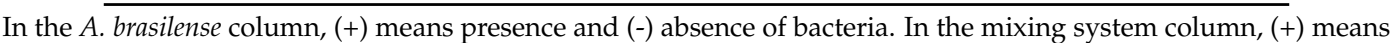
aeration and (-) means magnetic stirring. In the nitrogen column, $(+)$ means high nitrogen concentration and (-) means low nitrogen concentration.

Results were evaluated using one-way analysis of variance (ANOVA) using Minitab 17 and Minitab Express software, in order to determine which factors are statistically significant. Then, to compare the different treatments the Fisher test was applied. An alpha level of 5\% was considered significant for all comparisons.

\subsection{Growth and Biomass Analysis}

\subsubsection{Biomass Growth}

Optical density was measured daily after inoculation at a wavelength of $750 \mathrm{~nm}$ to minimize the interference by pigments [39]. Counting of microalgae cells was performed with a Neubauer chamber (Auxilab 30100011, Beriain, Navarra, Spain).

For cell counting a $20 \mu \mathrm{L}$ sample was placed in the Neubauer chamber, allowed to repose for $2 \mathrm{~min}$, and counted under $40 \times$ objective in a bright-field microscope equipped with a digital camera (Scopetek Opto-Electric DCM 200, Hangzhou, China). Counting was performed in duplicate. Correlation curves of $\mathrm{OD}_{750}$ and dry weight (DW) were done according to Griffiths et al. [39].

For the biomass concentration estimation data from the correlation curves of $\mathrm{OD}_{750}$ was used. To analyze the total biomass production, $50 \mathrm{~mL}$ of each replicate were filtered at the end of the exponential growth phase (at about 15 days from the inoculation) using pre-weighed $0.45 \mu \mathrm{m}$ cellulose nitrate membranes, rinsed with distilled water and dryed at $105^{\circ} \mathrm{C}$ for $8 \mathrm{~h}$.

Growth monitoring was stopped when the cultures finished the exponential growth phase. Biomass was harvested by centrifugation (Centurion 4000r, Chichester, West Sussex, UK) at $2500 \mathrm{rpm}$ for $10 \mathrm{~min}$ and freeze-dried (VirTis BT6K, Warminster, PA, USA) for biomass analysis.

\subsubsection{Cell Size}

Scenedesmus sp. is typically found in colonies of four cells inside a parental mother wall named coenobium. The coenobium area was determined at the end of the runs by image analysis using the AutoCAD2015 software to measure cell length and width.

To calibrate measurements, Neubauer chamber small squares $(50 \mu \mathrm{m})$ were used as scale. 
For statistical analysis, 25 cells of each treatment replicate were considered.

\subsubsection{Biomass Analysis}

For biomass analysis, biomass was harvested by centrifugation (Centurion 4000r, Chichester, West Sussex, UK) at $2500 \mathrm{rpm}$ for $10 \mathrm{~min}$ and freeze-dried (VirTis BT6K, Warminster, PA, USA). The biomass analysis was performed for the whole co-culture of microalgae and bacteria.

Carbohydrates were determined from the freeze-dried biomass $(5 \mathrm{mg})$, according to Dubois et al. [40], using glucose as standard.

Protein content was determined on the freeze-dried biomass (5 mg), according to Lowry et al. [41], using bovine serum albumin as standard. Determinations were performed in duplicate.

Fatty acids were determined on the freeze-dried biomass $(10 \mathrm{mg})$ in a simultaneous extraction/methylation process following the methodology of Ryckebosch et al. [42]. $2 \mathrm{~mL}$ of chloroform/methanol $(2: 1 \mathrm{v} / \mathrm{v})$ were used as extraction reagent. Later, $1 \mathrm{~mL}$ of Arachidic acid C20:0 (25 mg/100 mL chloroform) was added to the samples as an internal standard, followed by the addition of $1 \mathrm{~mL}$ of methanol. Sulfuric acid $(300 \mu \mathrm{L})$ was used as catalyst for the esterification reaction. The mixture was placed under a water bath at $100{ }^{\circ} \mathrm{C}$ for $10 \mathrm{~min}$, and then cooled to room temperature. Later, $1 \mathrm{~mL}$ of water was added, and the lower layer (organic phase) was extracted, filtered (Whatman 1) over anhydrous sodium sulfate, and transferred to a new glass tube. The solvent was evaporated using $\mathrm{N}_{2}$, and the extract was re-dissolved with $1.5 \mathrm{~mL}$ hexane for gas chromatography analysis. The fatty acids (FA) profile was analyzed by gas chromatography (GC) with cold on-column injection and a flame ionization detector (FID) (Trace GC Ultra, Thermo Scientific, Belgium). An EC Wax column of $30 \mathrm{~m}$ length, $0.32 \mathrm{~mm}$ internal diameter, and $0.25 \mu \mathrm{m}$ film (Grace, Belgium) was used with the following time-temperature program: $70-180{ }^{\circ} \mathrm{C}\left(5^{\circ} \mathrm{C} \cdot \mathrm{min}^{-1}\right), 180-235^{\circ} \mathrm{C}\left(2{ }^{\circ} \mathrm{C} \cdot \mathrm{min}^{-1}\right)$, and $235^{\circ} \mathrm{C}(9.5 \mathrm{~min})$. Peak areas were quantified with ChromCard for Windows software (Interscience, Belgium). Fatty acids standards (Nu-check, USA) containing a total of 35 different fatty acids were analyzed for peak identification. Fatty acids determinations were performed in duplicates.

\section{Results and Discussion}

\subsection{Growth Analysis}

\subsubsection{Biomass and Growth Analysis}

To study the effect of $A$. brasilense in algal biomass productivity, 8 experimental treatments were performed, as shown in Table 1, corresponding the set of treatments to a $2^{3}$ experimental design. For all the 8 treatments, biomass growth was monitored from the inoculum to day 15 of the exponential growth phase, as shown in Figure 1. Comparing the various growth curves, it can be seen that although qualitatively similar, the experimental treatments containing Azospirillum (T1 to T4) reached on day 15, a higher average biomass concentration of $96 \pm 5 \mathrm{mg} \cdot \mathrm{L}^{-1}$, than treatments without bacteria (T5 to T8) of $91 \pm 9 \mathrm{mg} \cdot \mathrm{L}^{-1}$. Also, differences on biomass productivity are mainly observed after day 10 of the exponential growth phase.

Among treatments with Azospirillum, treatment T2, under aeration and with low nitrogen concentration, reached the highest average biomass concentration of $103 \pm 2 \mathrm{mg} \cdot \mathrm{L}^{-1}$ on day 15 of exponential growth, and had the highest average biomass productivity of $6 \pm 4 \mathrm{mg} \cdot \mathrm{L}^{-1} \cdot \mathrm{day}^{-1}$, considering all the 15 days, and of $11 \pm 7 \mathrm{mg} \cdot \mathrm{L}^{-1} \cdot$ day $^{-1}$, just considering the last 5 days of exponential growth, after day 10. Concerning the cultures without Azospirillum, treatment T6, also under aeration and with low nitrogen concentration, reached the highest average biomass concentration of $98 \pm 11 \mathrm{mg} \cdot \mathrm{L}^{-1}$ on day 15 of exponential growth, and had the highest average biomass productivity of $6 \pm 5 \mathrm{mg} \cdot \mathrm{L}^{-1} \cdot$ day $^{-1}$, considering all the 15 days, and of $11 \pm 8 \mathrm{mg} \cdot \mathrm{L}^{-1} \cdot$ day $^{-1}$, just considering the last 5 days of exponential growth. Therefore, aeration and low nitrogen concentration are two relevant factors influencing microalgae growth, with and without Azospirillum. 

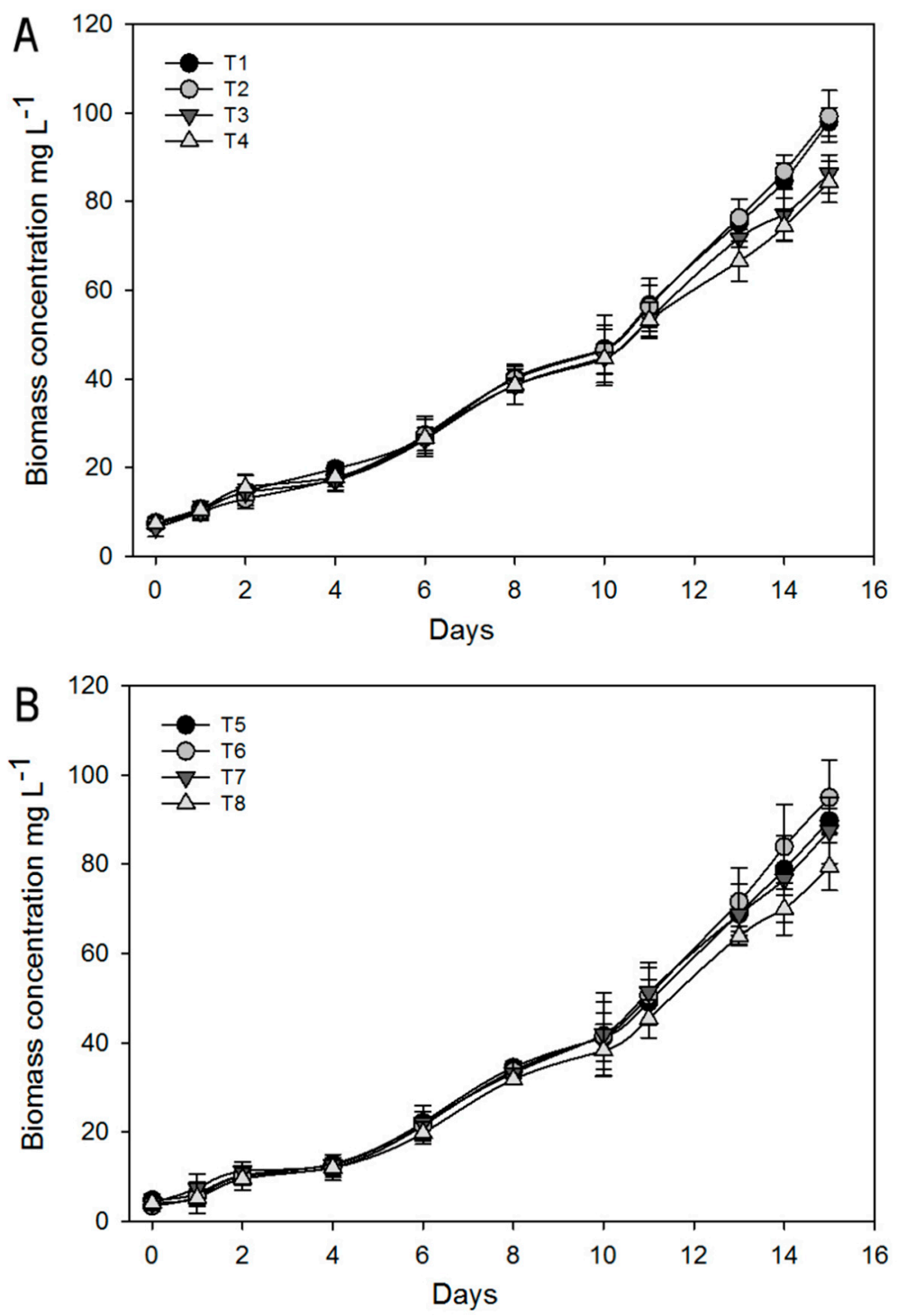

Figure 1. Biomass growth curves for the 8 treatments performed, from the inoculum to day 15 of the exponential growth phase. (A) treatments $\mathrm{T} 1$ to $\mathrm{T} 4$, and (B) treatments $\mathrm{T} 5$ to $\mathrm{T} 8$.

Graphs of Figure 2 present the growth parameter analysis of Scenedesmus sp. co-culturing with A. brasilense, evaluated at day 15 of the exponential growth phase, based on the biomass concentration, growth rate, and colony size. Results of the Fisher test are shown by letters (a, b, c, d) placed at the top of each bar. This way it is possible to identify if the treatments statistically differ from each other or are similar. Treatments sharing a same letter are statistically not different even if they have different average or standard deviation values, while treatments not sharing a common letter are statistically different from the remaining treatments $(p<0.05$ Fisher).

Biomass concentration expressed as dry weight is shown in Figure 2A. Results show that the presence of $A$. brasilense is statistically significant ( $p$-value: 0.034 ). On average, the experimental treatments containing Azospirillum had higher biomass concentration $\left(96 \pm 5 \mathrm{mg} \cdot \mathrm{L}^{-1}\right)$ than treatments without bacteria $\left(91 \pm 9 \mathrm{mg} \cdot \mathrm{L}^{-1}\right)$. The lowest biomass concentration $\left(83 \pm 7 \mathrm{mg} \cdot \mathrm{L}^{-1}\right)$ was achieved in treatment 8 , an experiment without $A$. brasilense and under magnetic stirring (Figure 2A). Normally, higher biomass production is related to higher cell concentration in microalgae cultures [43]. When working with MGPB, microalgae cells are in contact with substances that can enhance their growth, cell size and biomass composition [44]. A. brasilense co-culturing with cyanobacteria species has also been reported to increase biomass growth. Synechococcus elongatus immobilized in alginate 
beads with $A$. brasilense increased its specific growth rate and biomass production during wastewater treatment [27]. However, immobilized cultures represent higher costs.
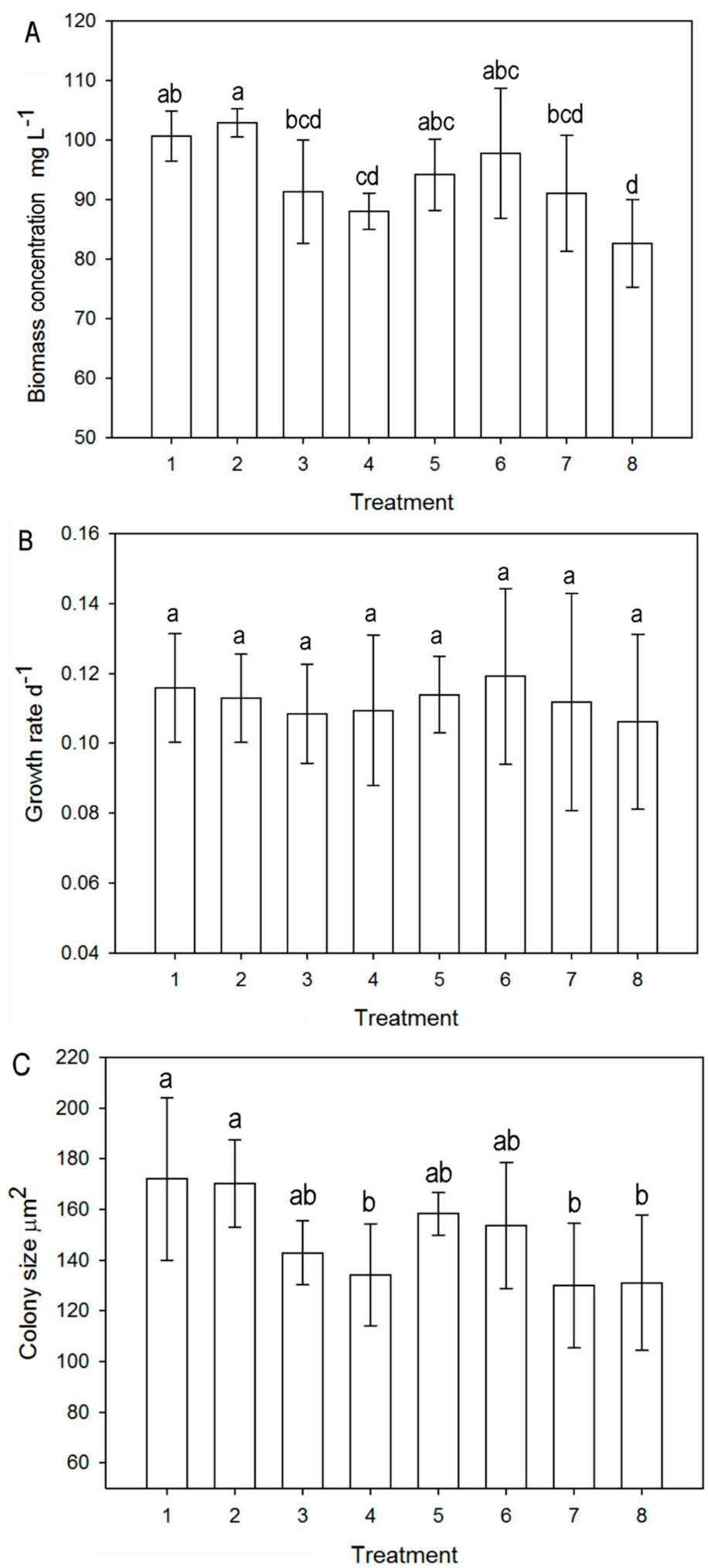

Figure 2. Growth parameter analysis of Scenedesmus sp. co-culturing with A. brasilense evaluated at day 15 of the exponential growth phase. (A) biomass concentration, (B) growth rate, and (C) colony size. In the graph, treatments not sharing a common letter $(a, b, c, d)$ differ significantly from each other $(p<0.05$ Fisher $)$. Error bars represent the standard deviation among replicates per treatment. 
The nature of the mixing system is also statistically significant ( $p$-value: 0.000 ), in particular aeration contributed to higher biomass production than the mechanical stirring. Notably, aeration in the presence of bacteria yielded the highest biomass production $\left(103 \pm 2 \mathrm{mg} \cdot \mathrm{L}^{-1}\right)$ in treatment 2 . This is explained because the mixing system directly affects the mass transfer of gases, in particular oxygen and carbon dioxide in the culture, and it is already known that the optimization of these factors can enhance Scenedesmus growth in photobioreactors [45].

Nitrogen is a critical nutrient for microalgae growth because it is used by the cells to grow through the production of proteins and nucleotides present in biomass [46]. Based on cell counting, Scenedesmus sp. did not show any significant difference on its specific growth rate when co-cultured with $A$. brasilense under different mixing conditions and nitrogen levels, as shown in Figure 2B. According to other studies, high nitrogen concentration increased biomass production of Scenedesmus [46]. A. brasilense, due to its nitrogen fixing capacity, can reduce the effect of low exogenous nitrogen concentration, as observed in the treatments with bacteria and low nitrogen concentration (treatments 2 and 4). In addition, nitrogen is one of the most important nutrients for microalgae growth. Therefore, microalgae biomass production using $A$. brasilense can reduce the need to add exogenous nitrogen loads in cultures, one of the main drawbacks in microalgae culture cost-effectiveness $[47,48]$.

\subsubsection{Growth in terms of Colony Size}

As shown in Figures 2C and 3, coenobium size of Scenedesmus sp. was affected by the presence of A. brasilense ( $p$-value: 0.044$)$. Co-culturing contributed in average, to higher colony size $\left(155 \pm 21 \mu \mathrm{m}^{2}\right)$ than without A. brasilense $\left(143 \pm 21 \mu \mathrm{m}^{2}\right)$. Also, colony size was affected by the mixing system ( $p$-value: $0.000)$. Aeration contributed to, in average, higher colony size $\left(164 \pm 21 \mu \mathrm{m}^{2}\right)$ than mechanical stirring $\left(134 \pm 21 \mu \mathrm{m}^{2}\right)$, because aeration contribute to better mass transfer of gases in the culture. The same number of cells (four) per colony, but bigger colony sizes, were found in treatment $1\left(172 \pm 32 \mu \mathrm{m}^{2}\right)$ with $A$. brasilense under continuous aeration and with the highest nitrogen concentration, while the lowest coenobium area was found in treatment $7\left(130 \pm 25 \mu \mathrm{m}^{2}\right)$, without $A$. brasilense, under magnetic stirring and with the highest nitrogen concentration.

Similar results were found with Chlorella sp. co-culturing with A. brasilense in immobilized cultures [23]. In the mentioned study, microalgae cells increased their size, but contrary to our results, A. brasilense enhanced Chlorella sp. growth rate in terms of cell number per volume of culture. Although considering a different co-culturing mode, in particular Scenedesmus sp. with A. brasilense in suspended cultures, the results obtained from cell size analysis are similar to the results obtained with other species such as Chlorella sorokiniana [24], Synechococcus elongatus [27] and Chlorella vulgaris [22] co-cultured with A. brasilense, but immobilized.

In order to identify the possible mechanisms involved in increasing cells size, previous reports suggest that phytohormones (such as IAA) produced by MGPB can induce significant changes in the microalgae metabolism, such as enhancing cell size [23], and are responsible for the ammonium uptake and assimilation in microalgae [49]. The exchange of IAA is independent of nitrogen fixation, and for the present study, it can explain the differences in cell size among treatments, even though we cannot see a significant difference in growth rate."

IAA, an auxin responsible of cell elongation and cell division, can be one of the substances implicated in the increment of cellular biomass production, therefore producing bigger cells [22]. Previous experiments reported that the addition of this phytohormone into Chlorella vulgaris media without $A$. brasilense emulates the effects of the bacteria in increasing microalgae biomass production in terms of dry weight, total number of cells, and cells size [22]. IAA produced by A. brasilense might be involved in ammonium uptake and its assimilation, leading to higher biomass production [49]. Since ammonium requires less energy from microalgae cells for its assimilation than other nitrogen sources [50], energy saved from nitrogen uptake process can be used to support other metabolic reactions, and can explain the higher colony size and biomass production. 


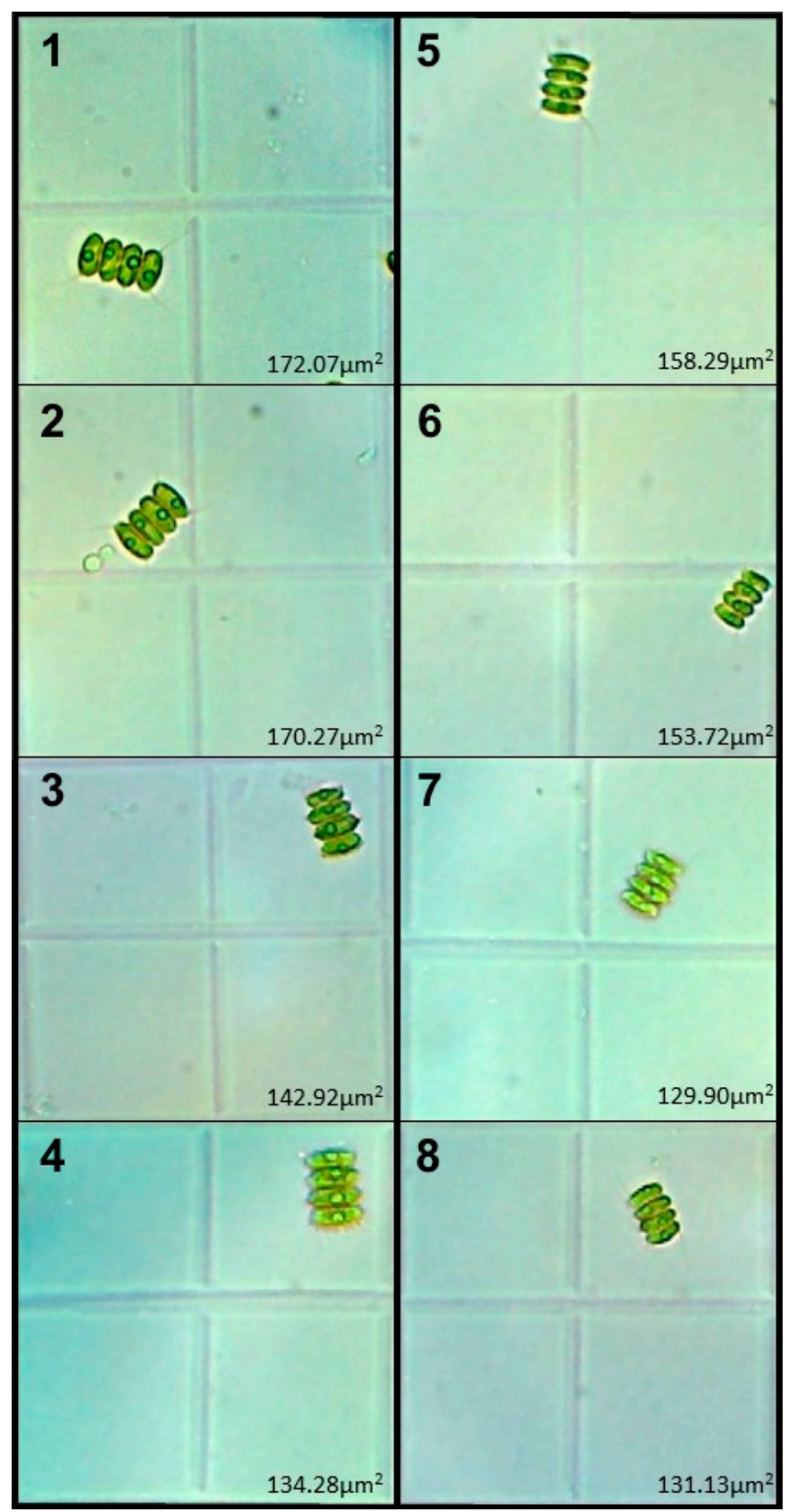

Figure 3. Colonies of the 8 different treatments visualized using a Neubauer chamber. Scenedesmus sp. coenobium size is shown for each treatment. For averages and standard deviation of the coenobium size, please refer to Figure $2 \mathrm{C}$.

\subsection{Analysis of Biomass Composition}

Growth under nitrogen deprivation is believed to induce decreases in protein productivity and to increase the productivity of lipids and carbohydrates of microalgae. However, the intensity of these processes greatly varies depending on the species tested and the experimental conditions [30,51,52]. The graph in Figure 4, presents the biomass analysis results in terms of protein, carbohydrate and fatty acids contents. Results of the Fisher test are shown by letters (a, b, c, d) placed at the top of each bar. Dry weight content of protein, carbohydrate or fatty acids was separately analyzed with the Fisher test. Therefore, results shown compare averages among treatments for a given biomass component (protein, carbohydrate or fatty acids). Treatments not sharing a common letter mean that the corresponding average values significantly differ from each other $(p<0.05$ Fisher $)$. 


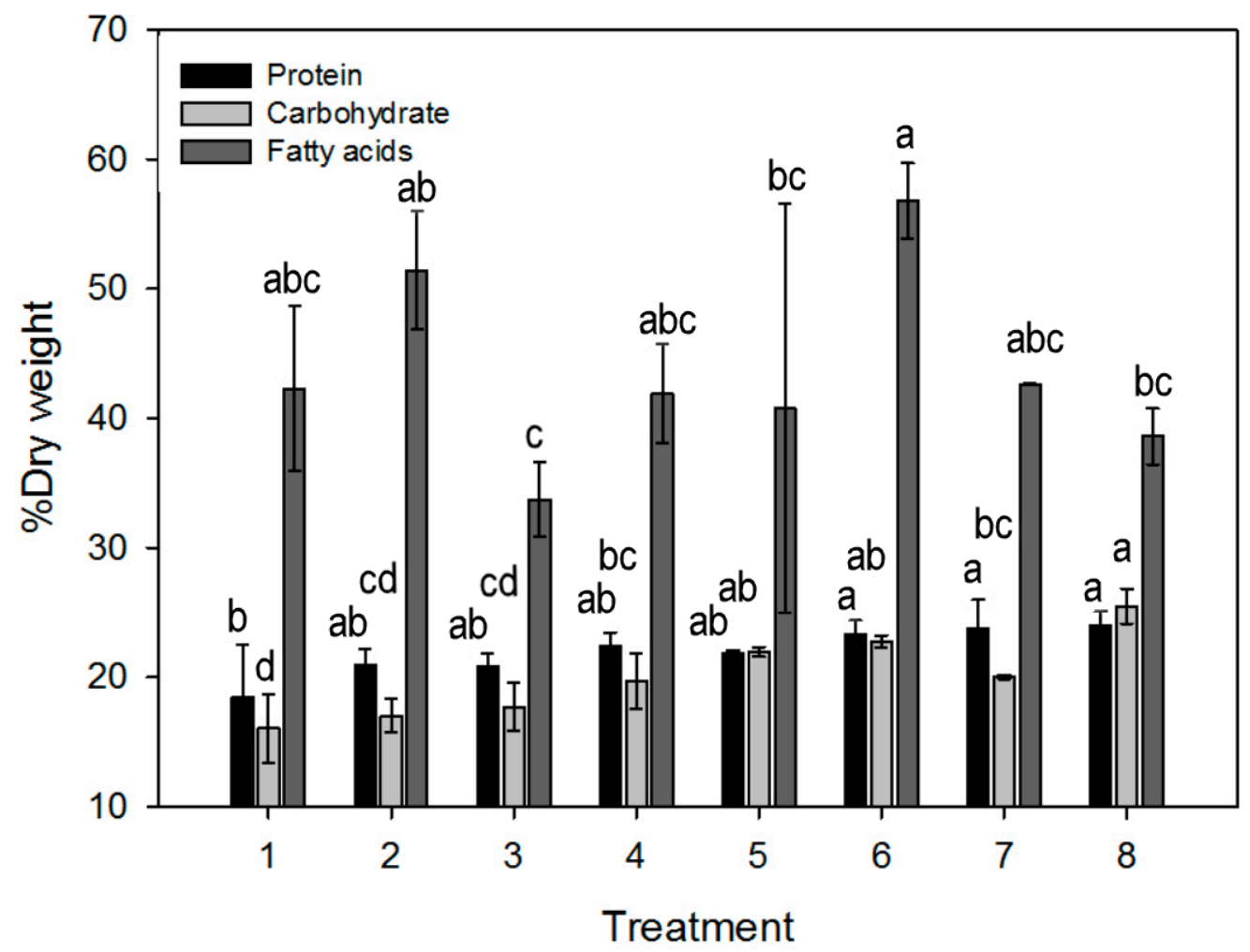

Figure 4. Biomass analysis results in terms of protein, carbohydrate and fatty acids content. Treatments not sharing a common letter $(\mathrm{a}, \mathrm{b}, \mathrm{c}, \mathrm{d})$ differ significantly from each other $(p<0.05$ Fisher $)$ for the protein, carbohydrate or fatty acid contents that are independently compared among treatments. Error bars represent the standard deviation among replicates per treatment.

\subsubsection{Protein Content}

In this study, protein content was affected by the presence of $A$. brasilense ( $p$-value: 0.019). Co-culturing treatments had an average protein content of $21 \pm 2 \%$ of dry cell weight (DW), while treatments without MGPB had an average of $23 \pm 1 \% \mathrm{DW}$. The lowest protein content $(19 \pm 4 \% \mathrm{DW})$ was found in treatment 1 , with $A$. brasilense, under aeration and sufficient nitrogen concentration, while the highest protein content $(24 \pm 1 \% \mathrm{DW})$ was found in treatment 8 , without $A$. brasilense, under magnetic stirring and with low nitrogen concentration in the culture media. These protein content values agree with the ones reported in literature for Scenedesmus sp. of 24.87-35.17\% DW [30]. Similarly, treatments with low nitrogen concentration had in average higher protein content $(23 \pm 1 \% \mathrm{DW})$ than those with sufficient nitrogen $(21 \pm 2 \% \mathrm{DW})$. Although a sufficient nitrogen medium may lead one to infer that the protein content will also be high, this and other literature studies [30,53] have shown the opposite, reporting for Scenedesmus a higher protein content when the nitrogen concentration in the media was lower.

When co-culturing with $A$. brasilense, higher nitrogen fixing activity and therefore higher protein levels are expected due to the absence of nitrogen deprivation. However, the mechanisms involved in nitrate uptake and protein synthesis are more complex and depend on several factors, greatly varying depending on the species tested and experimental conditions. It is already known that A. brasilense is able to establish cell to cell interactions with microalgae to sustain mutualistic symbiotic relations $[17,54]$. Also, significant increments in enzymatic activities were observed in literature studies [55] during the co-culturing of A. brasilense and Chlorella sorokiniana. This shows that the co-culturing of these two species involve other mechanisms different than the abiotic stresses, such as nitrogen deprivation. Therefore, its effect could modify metabolic pathways, thus changing the biomass composition in both microorganisms involved. 
The two main factors affecting protein content in co-culturing are the production of growth promoters and the biological nitrogen fixation from A. brasilense [26]. Based on growth promoters produced by $A$. brasilense it is known that during co-culturing with Chlorella sorokiniana, the microalgae provides tryptophan and thiamine to bacteria in exchange for IAA [55]. The exchange of amino acids to produce growth promoters and the effect of growth promoters itself can affect biomass growth and composition, including protein content, thus explaining the differences between protein content with and without $A$. brasilense in the culture. Further research is required to better understand changes in the proteome of Scenedesmus sp. in co-culturing with A. brasilense in suspended cultures.

\subsubsection{Carbohydrate Content}

Carbohydrate content of Scenedesmus species has been reported to differ, depending on culture conditions and strains [56]. Different strains of Scenedesmus obliquus were reported to have carbohydrate content between 6 and 47\% of DW depending on light intensities and nutrient deprivation [50]. Scenedesmus sp. and Chlorella sp. carbohydrate content has been reported to depend on the nitrogen concentration in the culture media as higher carbohydrate contents were obtained under lower nitrogen concentration, similar to this study results [51].

In this study, carbohydrate content followed the same pattern already observed for protein content in terms of $A$. brasilense effect ( $p$-value: 0.000 ). This can be seen in Figure 4 that shows that co-culturing treatments had an average carbohydrate content of $18 \pm 2 \%$ of dry cell weight (DW), while treatments without MGPB had an average of $23 \pm 1 \%$ DW. Similarly, nitrogen contributed significantly to carbohydrates content ( $p$-value: 0.001 ). Treatments with low nitrogen concentration had in average higher carbohydrate content $(21 \pm 1 \% \mathrm{DW})$ than those with sufficient nitrogen $(19 \pm 1 \%$ DW). This explained because when microalgae cells are nitrogen deprived, metabolism changes to the accumulation of lipids or carbohydrates [51].

The highest carbohydrate content of $26 \pm 1 \%$ DW (treatment 8 , Figure 4) was obtained in culture without bacteria, low nitrogen concentration, and under magnetic stirring, while the lowest carbohydrate content of $16 \pm 3 \%$ DW (treatment 1, Figure 4), was obtained in co-culture with bacteria, sufficient nitrogen and continuous aeration, supporting the conclusion that $A$. brasilense allows the microalgae to obtain enough nitrogen and limiting their need to produce carbohydrates.

\subsubsection{Fatty Acid Content and Profile}

High nitrogen levels are related with low lipid accumulation in Scenedesmus species [52], because higher nitrogen levels were shown to be enough to avoid nutrient stress, yielding lower fatty acid content. In this study, results show that the fatty acids content was affected by the nitrogen concentration in the media ( $p$-value: 0.027 ). Treatments with low nitrogen concentration had in average higher fatty acid content ( $47 \pm 3 \% \mathrm{DW})$ than those with sufficient nitrogen $(40 \pm 6 \% \mathrm{DW})$. Similarly, co-culturing treatments had an average carbohydrate content of $42 \pm 4 \% \mathrm{DW}$, while treatments without MGPB had an average of $45 \pm 6 \%$ DW. The highest fatty acid content of $57 \pm 3 \%$ DW was obtained in treatment 6, without bacteria and low nitrogen concentration, followed by treatment $2(51 \pm 5 \%$ DW) with bacteria and low nitrogen concentration. This can be explained because in treatment 2, in co-culturing, $\mathrm{N}$ is expected to be supplied through the nitrogen fixation relation. It is reported for Scenedesmus species, lipid contents of $50-80 \%$ measured gravimetrically [28], when using nitrogen and phosphorus deprivation strategies [31]. Thus, the values of fatty acid content, obtained in the present study, are within the literature range. Results also show that the fatty acids content was affected by the different mixing systems ( $p$-value: 0.015 ). Comparing the mixing systems, aeration led in average to higher fatty acid content $(48 \pm 7 \% \mathrm{DW})$ than magnetic stirring $(39 \pm 2 \% \mathrm{DW})$, which can be explained since the carbon dioxide mass transfer is increased by aeration. This response in fatty acids accumulation by Scenedesmus cells has been previously reported, indicating its capacity for carbon fixation $[52,57]$. 
Table 2 presents the fatty acid profile of biomass obtained for each experimental treatment, showing that the unsaturated fatty acids (UFA) represent more than $80 \%$ of the total fatty acids (FA) content in all treatments, in which UFA with 18 carbons were predominant, as previously reported for Scenedesmus species $[31,56,58]$. Higher content of saturated fatty acids (SFA) was obtained in treatments with magnetic stirring. Further metabolic research is required to understand how carbon dioxide mass transfer affects fatty acid metabolism.

Table 2. Fatty acid profile of biomass in dry weight percentage.

\begin{tabular}{|c|c|c|c|c|c|c|c|c|}
\hline \multirow{2}{*}{$\begin{array}{l}\text { Fatty Acid } \\
\text { (FA) }\end{array}$} & \multicolumn{8}{|c|}{ Treatments } \\
\hline & 1 & 2 & 3 & 4 & 5 & 6 & 7 & 8 \\
\hline C14:0 & $0.3 \% \pm 0.3$ & $0.8 \% \pm 0.1$ & $0.5 \% \pm 0.3$ & $0.3 \% \pm 0.1$ & $0.4 \% \pm 0.1$ & $0.8 \% \pm 0.3$ & $0.6 \% \pm 0.2$ & $0.9 \% \pm 0.3$ \\
\hline C16:1 & $0.6 \% \pm 0.4$ & $0.2 \% \pm 0.1$ & $0.7 \% \pm 0.9$ & $0.2 \% \pm 0.1$ & $0.6 \% \pm 0.6$ & $0.7 \% \pm 0.7$ & $0.6 \% \pm 0.7$ & $0.5 \% \pm 0.4$ \\
\hline C18:1 & $2.0 \% \pm 0.7$ & $2.4 \% \pm 0.3$ & $3.5 \% \pm 1.8$ & $3.0 \% \pm 0.2$ & $2.4 \% \pm 0.2$ & $2.8 \% \pm 0.4$ & $3.5 \% \pm 0.8$ & $3.7 \% \pm 1.1$ \\
\hline C18:2 & $2.9 \% \pm 1.0$ & $3.9 \% \pm 0.5$ & $4.8 \% \pm 1.7$ & $4.8 \% \pm 0.4$ & $3.7 \% \pm 0.2$ & $4.4 \% \pm 0.1$ & $5.4 \% \pm 0.3$ & $5.2 \% \pm 0.2$ \\
\hline $\mathrm{C} 18: 3 \mathrm{n} 3$ & $30.9 \% \pm 3.1$ & $37.2 \% \pm 6.2$ & $17.6 \% \pm 3.6$ & $27.4 \% \pm 2.1$ & $26.9 \% \pm 15.9$ & $40.5 \% \pm 2.4$ & $25.1 \% \pm 1.9$ & $20.6 \% \pm 0.8$ \\
\hline Total FA (\%) & $42.3 \% \pm 6.3$ & $51.4 \% \pm 4.5$ & $33.7 \% \pm 2.9$ & $41.9 \% \pm 3.8$ & $40.7 \% \pm 15.8$ & $56.8 \% \pm 2.9$ & $42.6 \% \pm 0.1$ & $38.6 \% \pm 2.2$ \\
\hline SFA $(\%)$ & 10.3 & 10.9 & 16.5 & 11.9 & 13.2 & 10.9 & 14.8 & 17.2 \\
\hline UFA (\%) & 89.7 & 89.1 & 83.5 & 88.1 & 86.8 & 89.1 & 85.2 & 82.8 \\
\hline
\end{tabular}

SFA = saturated fatty acids; UFA = unsaturated fatty acids.

\section{Conclusions}

Microalgae biomass production for different applications, such as wastewater treatment and biofuels, is limited by several factors, such as nitrogen availability and mass transfer limitations. This work demonstrated that Scenedesmus sp. and A. brasilense co-culturing can be effectively performed on nitrogen-deficient media and in suspended cultures, without requiring immobilization of cultures, contributing to decrease nitrogen and energy inputs, while producing biomass for biofuels. Results show that in average, cultures with aeration reached higher biomass production, colony size and fatty acid content. The highest biomass concentration was obtained under aeration, with low nitrogen concentration, in the presence of $A$. brasilense. In particular, aeration contributed to higher fatty acid content and higher colony size than mechanical stirring. Also, co-culturing contributed in average, to higher colony size than without bacteria. Since A. brasilense is already approved and extensively used in agriculture and in wastewater treatment, without known environmental or health issues, there is no need to separate the bacteria from the resulting biomass, simplifying the cultivation and biomass processing for the desired final application such as biofuels production. Future research on long-term co-culture is expected to better explain the mutualist relationship between bacteria and microalgae and improve performance of co-culture systems.

Author Contributions: J.R.C.-A. designed the experimental set-up, prepared microalgae cultures, analyzed the samples, performed data analysis and wrote the manuscript; T.M.M., N.S.C. and S.P.C.-B. contributed with lab work and revised the data analysis and statistics; R.C. and J.S.G.-P. contributed with data analysis, figures design and revised the manuscript. T.M.M., N.S.C., K.M. and R.P.-S. approved the experimental set-up and critically reviewed the manuscript.

Funding: This research was funded by: project IF/01093/2014/CP1249/CT0003; research grant IF/01093/2014, and Center for Innovation in Engineering and Industrial Technology-CIETI, UID/EQU/00305/2013. This work was financially supported by: project UID/EQU/00511/2019-Laboratory for Process Engineering, Environment, Biotechnology and Energy-LEPABE funded by national funds through FCT/MCTES (PIDDAC); Project POCI-01-0145-FEDER-006939 (Laboratory for Process Engineering, Environment, Biotechnology and Energy_LEPABE, UID/EQU/00511/2013) funded by FEDER through COMPETE2020-POCI and by national funds through FCT; Project "LEPABE-2-ECO-INNOVATION"-NORTE-01-0145-FEDER-000005, funded by Norte Portugal Regional Operational Programme (NORTE 2020), under PORTUGAL 2020 Partnership Agreement, through the European Regional Development Fund (ERDF). This research has been partially funded by the Tec de Monterrey and MIT Nanotechnology Program. 
Acknowledgments: CONACyT (Mexican Council of Science and Technology) gratefully acknowledge the support and assistance provided to José Ramón Contreras Angulo during this research work at the University of Porto. We thank Mauricio A. Trujillo Roldan and Biofabrica Siglo XXI for the advising and support during the establishment of A. brasilense cultures.

Conflicts of Interest: The authors declare no conflict of interest.

\section{References}

1. Mata, T.M.; Caetano, N.S.; Martins, A.A. Microalgae for biodiesel production and other applications: A review. Renew. Sustain. Energy Rev. 2010, 14, 217-232. [CrossRef]

2. Cuellar-Bermudez, S.P.; Aguilar-Hernandez, I.; Cardenas-Chavez, D.L.; Ornelas-Soto, N.; Romero-Ogawa, M.A.; Parra-Saldivar, R. Extraction and purification of high-value metabolites from microalgae: Essential lipids, astaxanthin and phycobiliproteins. Microb. Biotechnol. 2015, 8, $190-209$. [CrossRef] [PubMed]

3. Zhu, L. Biorefinery as a promising approach to promote microalgae industry: An innovative framework. Renew. Sustain. Energy Rev. 2015, 41, 1376-1384. [CrossRef]

4. Gupta, S.; Pawar, S.B. An integrated approach for microalgae cultivation using raw and anaerobic digested wastewaters from food processing industry. Bioresour. Technol. 2018, 269, 571-576. [CrossRef]

5. Broderick, T.A.; Sherrard, J.H. Treatment of nutrient deficient wastewaters. J. Water Pollut. Control Fed. 1985, $57,1178-1182$.

6. Esvelt, L.A.; Hart, H.H. Treatment of fruit processing waste by aeration. J. Water Pollut. Contr. Fed. 1970, 42, 1305-1326.

7. Kargi, F.; Özmihçi, S. Improved biological treatment of nitrogen-deficient wastewater by incorporation of N2-fixing bacteria. Biotechnol. Lett. 2002, 24, 1281-1284. [CrossRef]

8. Cuellar-Bermudez, S.P.; Aleman-Nava, G.S.; Chandra, R.; Garcia-Perez, J.S.; Contreras-Angulo, J.R.; Markou, G.; Muylaert, K.; Rittmann, B.E.; Parra-Saldivar, R. Nutrients utilization and contaminants removal. A review of two approaches of algae and cyanobacteria in wastewater. Algal Res. 2017, 24, 438-449. [CrossRef]

9. Lananan, F.; Abdul Hamid, S.H.; Din, W.N.S.; Ali, N.; Khatoon, H.; Jusoh, A.; Endut, A. Symbiotic bioremediation of aquaculture wastewater in reducing ammonia and phosphorus utilizing effective microorganism (EM-1) and microalgae (Chlorella sp.). Int. Biodeterior. Biodegrad. 2014, 95, 127-134. [CrossRef]

10. He, Q.; Yang, H.; Hu, C. Culture modes and financial evaluation of two oleaginous microalgae for biodiesel production in desert area with open raceway pond. Bioresour. Technol. 2016, 218, 571-579. [CrossRef]

11. Jorquera, O.; Kiperstok, A.; Sales, E.A.; Embiruçu, M.; Ghirardi, M.L. Comparative energy life-cycle analyses of microalgal biomass production in open ponds and photobioreactors. Bioresour. Technol. 2010, 101, 1406-1413. [CrossRef] [PubMed]

12. Muylaert, K.; Vandamme, D.; Foubert, I.; Brady, P.V. Harvesting of microalgae by means of flocculation. In Biomass and Biofuels from Microalgae; Springer International Publishing: Cham, Switzerland, 2015; pp. 251-273.

13. Psycha, M.; Pyrgakis, K.; Kokossis, A.C. Process design analysis for the valorisation and selection of integrated micro-algae biorefineries. Comput. Aided Chem. Eng. 2014, 33, 1543-1548.

14. Tijani, H.; Abdullah, N.; Yuzir, A. Integration of microalgae biomass in biomethanation systems. Renew. Sustain. Energy Rev. 2015, 52, 1610-1622. [CrossRef]

15. Bai, X.; Lant, P.; Pratt, S. The contribution of bacteria to algal growth by carbon cycling. Biotechnol. Bioeng. 2015, 112, 688-695. [CrossRef] [PubMed]

16. Mujtaba, G.; Lee, K. Advanced treatment of wastewater using symbiotic co-culture of microalgae and bacteria. Appl. Chem. Eng. 2016, 27, 1-9. [CrossRef]

17. De-Bashan, L.E.; Mayali, X.; Bebout, B.M.; Weber, P.K.; Detweiler, A.M.; Hernandez, J.-P.; Prufert-Bebout, L.; Bashan, Y. Establishment of stable synthetic mutualism without co-evolution between microalgae and bacteria demonstrated by mutual transfer of metabolites (NanoSIMS isotopic imaging) and persistent physical association (Fluorescent in situ hybridization). Algal Res. 2016, 15, 179-186. [CrossRef]

18. Glick, B.R. Plant Growth-promoting bacteria: Mechanisms and applications. Scientifica (Cairo) 2012, 2012, 1-15. [CrossRef] [PubMed] 
19. De-Bashan, L.E.; Antoun, H.; Bashan, Y. Involvement of Indole-3-Acetic acid produced by the growth-promoting bacterium Azospirillum ssp. in promoting growth of Chlorella vulgaris. J. Phycol. 2008, 44, 938-947. [CrossRef]

20. Ramanan, R.; Kim, B.-H.; Cho, D.-H.; Oh, H.-M.; Kim, H.-S. Algae-bacteria interactions: Evolution, ecology and emerging applications. Biotechnol. Adv. 2016, 34, 14-29. [CrossRef]

21. BPDB: Bio-Pesticides DataBase, Azospirillum brasilense. University of Hertfordshire. Available online: http:/ / sitem.herts.ac.uk/aeru/bpdb/Reports/1947.htm (accessed on 10 December 2018).

22. Gonzalez, L.E.; Bashan, Y. Increased Growth of the Microalga Chlorella vulgaris when Coimmobilized and Cocultured in Alginate Beads with the Plant-Growth-Promoting Bacterium Azospirillum brasilense. Appl. Environ. Microbiol. 2000, 66, 1527-1531. [CrossRef] [PubMed]

23. De-Bashan, L.E.; Bashan, Y.; Moreno, M.; Lebsky, V.K.; Bustillos, J.J. Increased pigment and lipid content, lipid variety, and cell and population size of the microalgae Chlorella spp. when co-immobilized in alginate beads with the microalgae-growth-promoting bacterium Azospirillum brasilense. Can. J. Microbiol. 2002, 48, 514-521. [CrossRef] [PubMed]

24. De-Bashan, L.E.; Moreno, M.; Hernandez, J.-P.; Bashan, Y. Removal of ammonium and phosphorus ions from synthetic wastewater by the microalgae Chlorella vulgaris coimmobilized in alginate beads with the microalgae growth-promoting bacterium Azospirillum brasilense. Water Res. 2002, 36, 2941-2948. [CrossRef]

25. Choix, F.J.; de-Bashan, L.E.; Bashan, Y. Enhanced accumulation of starch and total carbohydrates in alginate-immobilized Chlorella spp. induced by Azospirillum brasilense: II. Heterotrophic conditions. Enzyme Microb. Technol. 2012, 51, 300-309. [CrossRef] [PubMed]

26. De-Bashan, L.E.; Hernandez, J.P.; Bashan, Y. Interaction of Azospirillum spp. with Microalgae: A Basic Eukaryotic-Prokaryotic Model and Its Biotechnological Applications. In Handbook for Azospirillum; Springer International Publishing: Cham, Switzerland, 2015; pp. 367-388.

27. Ruiz-Güereca, D.A.; del Pilar Sánchez-Saavedra, M. Growth and phosphorus removal by Synechococcus elongatus co-immobilized in alginate beads with Azospirillum brasilense. J. Appl. Phycol. 2016, 28, 1501-1507. [CrossRef]

28. Eustance, E.; Wray, J.T.; Badvipour, S.; Sommerfeld, M.R. The effects of cultivation depth, areal density, and nutrient level on lipid accumulation of Scenedesmus acutus in outdoor raceway ponds. J. Appl. Phycol. 2016, 28, 1459-1469. [CrossRef]

29. Mata, T.M.; Melo, A.C.; Simões, M.; Caetano, N.S. Parametric study of a brewery effluent treatment by microalgae Scenedesmus obliquus. Bioresour. Technol. 2012, 107, 151-158. [CrossRef] [PubMed]

30. Quevedo, C.; Morales, S.P.; Acosta, A. Scenedesmus sp. growth in different culture mediums for microalgal protein production. VitaeRevista La Fac. Quim. Farm. 2008, 15, 25-31.

31. Shen, X.-F.; Liu, J.-J.; Chu, F.-F.; Lam, P.K.S.; Zeng, R.J. Enhancement of FAME productivity of Scenedesmus obliquus by combining nitrogen deficiency with sufficient phosphorus supply in heterotrophic cultivation. Appl. Energy 2015, 158, 348-354. [CrossRef]

32. Mata, T.M.; Melo, A.C.; Meireles, S.; Mendes, A.M.; Martins, A.A.; Caetano, N.S. Potential of microalgae Scenedesmus obliquus grown in brewery wastewater for biodiesel production. Chem. Eng. Trans. 2013, 32. [CrossRef]

33. Limón, P.; Malheiro, R.; Casal, S.; Acién-Fernández, F.G.; Fernández-Sevilla, J.M.; Rodrigues, N.; Cruz, R.; Bermejo, R.; Pereira, J.A. Improvement of stability and carotenoids fraction of virgin olive oils by addition of microalgae Scenedesmus almeriensis extracts. Food Chem. 2015, 175, 203-211. [CrossRef]

34. Rengifo-Gallego, A.L.; Salamanca, E.J.P. Interaction Algae-Bacteria Consortia: A new application of heavy metals bioremediation. In Phytoremediation; Springer International Publishing: Cham, Switzerland, 2015; pp. 63-73.

35. Tang, X.; He, L.Y.; Tao, X.Q.; Dang, Z.; Guo, C.L.; Lu, G.N.; Yi, X.Y. Construction of an artificial microalgal-bacterial consortium that efficiently degrades crude oil. J. Hazard. Mater. 2010, 181, 1158-1162. [CrossRef] [PubMed]

36. Hartmann, A.; Burris, R.H. Regulation of nitrogenase activity by oxygen in Azospirillum brasilense and Azospirillum lipoferum. J. Bacteriol. 1987, 169, 944-948. [CrossRef]

37. Hartmann, A. Ecophysiological aspects of growth and nitrogen fixation in Azospirillum spp. In Nitrogen Fixation with Non-Legumes; Springer: Dordrecht, The Netherlands, 1989; pp. 123-136. 
38. Stein, J.R. Handbook of Phycological Methods, Culture Methods and Growth Measurements; Cambridge University Press: Cambridge, UK, 1973.

39. Griffiths, M.J.; Garcin, C.; Van Hille, R.P.; Harrison, S.T.L. Interference by pigment in the estimation of microalgal biomass concentration by optical density. J. Microbiol. Methods 2011, 85, 119-123. [CrossRef]

40. DuBois, M.; Gilles, K.A.; Hamilton, J.K.; Rebers, P.A.; Smith, F. Colorimetric method for determination of sugars and related substances. Anal. Chem. 1956, 28, 350-356. [CrossRef]

41. Lowry, O.H.; Rosebrough, N.J.; Farr, A.L.; Randall, R.J. Protein measurement with the Folin phenol reagent. J. Biol. Chem. 1951, 193, 265-275.

42. Ryckebosch, E.; Muylaert, K.; Foubert, I. Optimization of an analytical procedure for extraction of lipids from microalgae. J. Am. Oil Chem. Soc. 2012, 89, 189-198. [CrossRef]

43. Ruiz-Marin, A.; Mendoza-Espinosa, L.G.; Stephenson, T. Growth and nutrient removal in free and immobilized green algae in batch and semi-continuous cultures treating real wastewater. Bioresour. Technol. 2010, 101, 58-64. [CrossRef] [PubMed]

44. De-Bashan, L.E.; Hernandez, J.-P.; Morey, T.; Bashan, Y. Microalgae growth-promoting bacteria as "helpers" for microalgae: A novel approach for removing ammonium and phosphorus from municipal wastewater. Water Res. 2004, 38, 466-474. [CrossRef] [PubMed]

45. Guo, X.; Yao, L.; Huang, Q. Aeration and mass transfer optimization in a rectangular airlift loop photobioreactor for the production of microalgae. Bioresour. Technol. 2015, 190, 189-195. [CrossRef] [PubMed]

46. Xin, L.; Hu, H.; Ke, G.; Sun, Y. Effects of different nitrogen and phosphorus concentrations on the growth, nutrient uptake, and lipid accumulation of a freshwater microalga Scenedesmus sp. Bioresour. Technol. 2010, 101, 5494-5500. [CrossRef]

47. Cabanelas, I.T.D.; Ruiz, J.; Arbib, Z.; Chinalia, F.A.; Garrido-Pérez, C.; Rogalla, F.; Nascimento, I.A.; Perales, J.A. Comparing the use of different domestic wastewaters for coupling microalgal production and nutrient removal. Bioresour. Technol. 2013, 131, 429-436. [CrossRef] [PubMed]

48. Tian-Yuan, Z.; Yin-Hu, W.; Shu-Feng, Z.; Feng-Min, L.; Hong-Ying, H. Isolation and heterotrophic cultivation of mixotrophic microalgae strains for domestic wastewater treatment and lipid production under dark condition. Bioresour. Technol. 2013, 149, 586-589.

49. Meza, B.; de-Bashan, L.E.; Bashan, Y. Involvement of indole-3-acetic acid produced by Azospirillum brasilense in accumulating intracellular ammonium in Chlorella vulgaris. Res. Microbiol. 2015, 166, 72-83. [CrossRef] [PubMed]

50. Grobbelaar, J.U. Inorganic algal nutrition. In Handbook of Microalgal Culture; John Wiley \& Sons, Ltd.: Oxford, UK, 2013; pp. 123-133.

51. Beuckels, A.; Smolders, E.; Muylaert, K. Nitrogen availability influences phosphorus removal in microalgae-based wastewater treatment. Water Res. 2015, 77, 98-106. [CrossRef]

52. Anand, J.; Arumugam, M. Enhanced lipid accumulation and biomass yield of Scenedesmus quadricauda under nitrogen starved condition. Bioresour. Technol. 2015, 188, 190-194. [CrossRef]

53. Apandi, N.M.; Radin Mohamed, R.M.S.; Latiffi, N.A.A.; Rozlan, N.F.M.; Al-Gheethi, A.A.S. Protein and Lipid Content of Microalgae Scenedesmus sp. Biomass Grown in Wet Market Wastewater. MATEC Web Conf. 2017, 103, 06011. [CrossRef]

54. De-Bashan, L.E.; Schmid, M.; Rothballer, M.; Hartmann, A.; Bashan, Y. Cell-cell interaction in the eukaryote-prokaryote model of the microalgae Chlorella vulgaris and the bacterium Azospirillum brasilense immobilized in polymer beads. J. Phycol. 2011, 47, 1350-1359. [CrossRef]

55. Palacios, O.A.; Gomez-Anduro, G.; Bashan, Y.; De-Bashan, L.E. Tryptophan, thiamine and indole-3-acetic acid exchange between Chlorella sorokiniana and the plant growth-promoting bacterium Azospirillum brasilense. FEMS Microbiol. Ecol. 2016, 92, fiw077. [CrossRef]

56. Ho, S.-H.; Chen, C.-Y.; Chang, J.-S. Effect of light intensity and nitrogen starvation on $\mathrm{CO}_{2}$ fixation and lipid/carbohydrate production of an indigenous microalga Scenedesmus obliquus CNW-N. Bioresour. Technol. 2012, 113, 244-252. [CrossRef] 
57. Yoo, C.; Jun, S.-Y.; Lee, J.-Y.; Ahn, C.-Y.; Oh, H.-M. Selection of microalgae for lipid production under high levels carbon dioxide. Bioresour. Technol. 2010, 101, S71-S74. [CrossRef]

58. Kozlova, T.A.; Hardy, B.P.; Krishna, P.; Levin, D.B. Effect of phytohormones on growth and accumulation of pigments and fatty acids in the microalgae Scenedesmus quadricauda. Algal Res. 2017, 27, 325-334. [CrossRef] 